\title{
Gill Development and Its Functional and Evolutionary Implications in the Blue Mussel Mytilus edulis (Bivalvia: Mytilidae)
}

\author{
ROZENN CANNUEL ${ }^{1}$, PETER G. BENINGER ${ }^{1, *}$, HELEN MCCOMBIE ${ }^{2}$, \\ AND PIERRE BOUDRY ${ }^{3, \dagger}$ \\ ${ }^{1}$ Laboratoire de Biologie Marine, Faculté des Sciences, Université de Nantes, 2 rue de la \\ Houssinière, BP 92208, 44322 Nantes Cedex 3, France; ${ }^{2}$ Centre for Applied Marine Sciences, \\ Bangor University, Menai Bridge, Anglesey LL59 5AB, United Kingdom; and ${ }^{3}$ Laboratoire de \\ Génétique et Pathologie, Institut Français de Recherche pour l'Exploitation de la Mer (IFREMER), \\ 17390 La Tremblade, France
}

\begin{abstract}
Study of gill development in bivalve larvae and postlarvae provides information on the evolution of this organ and feeding mechanisms of early stages. Scanning electron microscopy was used to document the development of the filibranch homorhabdic gill in hatchery-reared larval, postlarval, and juvenile Mytilus edulis. Four key stages were identified during gill development: (1) transfer of the particle collection function from velum to gill at metamorphosis, with subsequent elongation of the gill filaments to form a gill basket, with complete frontal ciliation; (2) reflection of the inner demibranchs, and transition to a V-shaped gill; (3) delayed development of the outer demibranchs, occuring simultaneously along the gill axis, with transition to the adult final W-shape; and (4) formation of the ventral particle grooves and concomitant acquisition of dense abfrontal ciliation. These key stages signal shifts in the mechanisms of particle processing during the early development of M. edulis. Gill development in the homorhabdic filibranch $M$. edulis was similar to that of the early homorhabdic stages of the heterorhabdic filibranchs studied to date (Pectinidae), but different from that of the pseudolamellibranchs (Ostreidae), suggesting divergent
\end{abstract}

Received 5 February 2008; accepted 13 July 2009.

* To whom correspondence should be addressed. E-mail: Peter.Beninger@univ-nantes.fr

†Current address: Laboratoire de Physiologie des Invertébrés, IFREMER, UMR PE2M, Centre de Brest, BP70, 29280 Plouzané, France.

Abbreviations: FSW, filtered seawater; ID, inner demibranch; OD, outer demibranch; SEM, scanning electron microscopy; SL, shell length. evolution of this character. Similarly, the systems responsible for gill cohesion and structural integrity are common to both the homorhabdic and heterorhabdic filibranchs, suggesting evolutionary proximity, but they are patently different from those of the eulamellibranchs and pseudolamellibranchs, suggesting evolutionary divergence.

\section{Introduction}

In suspension-feeding bivalves, the gills are the dominant site of interaction with the environment, mediated by the creation of water currents in the pallial cavity (particle processing, respiration, bioaccumulation, evacuation of propagules and wastes). Previous studies on the two most complex gill systems, the heterorhabdic filibranch (in Pectinidae, i.e., scallops) and pseudolamellibranch (in Ostreidae, i.e., oysters) have shown that gills make their first appearance in the pediveliger larval stage, and that their structural and functional complexity increase until achieving the definitive form in the juveniles (Waller, 1981; Kingzett, 1993; Beninger et al., 1994; Chaparro et al., 2001; Veniot et al., 2003; Cannuel and Beninger, 2006). The ontogeny of the bivalve gill has been studied sporadically over the past 150 years, in diverse species and developmental stages (Rice, 1908; Yonge, 1926; Quayle, 1952; Raven, 1958; Creek, 1960; Allen, 1961; Ansell, 1962; D’Asaro, 1967; Caddy, 1969; Bayne, 1971). Despite some remarkable work in the earlier studies, important aspects have not been adequately or coherently covered, such as ciliation, type of filament growth, and creation of junctions. 
To date, our investigations have demonstrated the existence of "critical stages" in bivalve gill ontogeny (stages at which gill structure and function undergo changes-transitions-which temporarily compromise efficient particle processing) (see Table 1). It has been repeatedly suggested that these critical stages may be associated with increased mortalities, which may in turn be problematic for both recruitment to natural populations and hatchery operations (Ó Foighil et al., 1990; Kingzett, 1993; Baker and Mann, 1994; Beninger et al., 1994; Veniot et al., 2003; Beninger and Cannuel, 2006; Cannuel and Beninger, 2006).

Studying the development of bivalve gills has led to new insights about the evolution of these feeding and respiratory structures and about the phylogenetic relationships among bivalve taxa (e.g., the Pectinidae and the Ostreidae-Beninger and Cannuel, 2006; Cannuel and Beninger, 2006). For a comprehensive understanding of these relationships, we require information about the most structurally simple gill type: the homorhabdic filibranch found, for example, in the family Mytilidae (Beninger and Dufour, 2000). This gill type is considered pleisiomorphic in the autobranchs, since both the heterorhabdic filibranchs and the pseudolamellibranchs show an early homorhabdic filibranch state during gill ontogeny (Kingzett, 1993; Beninger et al., 1994; Beninger and Dufour, 2000; Veniot et al., 2003; Cannuel and Beninger, 2006). Much early work on gill development in Mytilus sp. was performed over a century ago, with the equipment available at that time (LacazeDuthiers, 1856; Wilson, 1887; Rice, 1908; Field, 1922). The documentation in later work is extremely succinct, and extends only to immediate post-settlement (Bayne, 1971). The present work is the latest in a series of comparative studies of complete gill development in a set of bivalves selected as representative of particular adult gill morphologies, using the resolution and three-dimensional capabilities of modern scanning electron microscopy (SEM). Specifically, we investigate the ontogeny of the feeding structures in the homorhabdic filibranch Mytilidae, from the late larva to the adult, with a view to comparing critical stages and character development with those previously reported for the pseudolamellibranchs and heterorhabdic filibranchs.

\section{Materials and Methods}

\section{Larval production and rearing in larval, postlarval, and juvenile stages}

Parental mussels Mytilus edulis (Linnaeus, 1758) were collected from a long-line culture site at Charron in the Marennes-Oléron basin (Charente-Maritime, France; $46^{\circ} 17^{\prime} \mathrm{N}$, $01^{\circ} 06^{\prime} \mathrm{W}$ ), from the Gascogne Gulf patch (Bierne et al., 2003), and spawned by thermal induction (placing the individuals in seawater at different temperatures) at IFREMER La Tremblade. Oocytes and sperm were rinsed and sieved at $60 \mu \mathrm{m}$. Fertilizations were obtained in 1-1 beakers in $1-\mu \mathrm{m}$-filtered seawater (FSW). The developing embryos were transferred to
50-1 larval rearing tanks filled with aerated FSW within $1 \mathrm{~h}$ of successful fertilization. Resulting larvae, at an approximate density of 2 per milliliter at day 3 (D-larvae stage), were fed daily with a mixed diet (1:1) of Isochrysis galbana (Tahitian clone T-Iso) and Chaetoceros gracilis, at a cell concentration of $25,000 \mathrm{ml}^{-1}$ day $^{-1}$ until settlement. Tanks were emptied and cleaned every $2-3$ days. Once the eyed larval stage had been reached, coconut fiber ropes and plastic nets were immersed in the rearing tanks, allowing the settlement of the pediveliger larvae on these substrates. Feeding ration was increased to a cell concentration of $50,000 \mathrm{ml}^{-1}$ day $^{-1}$ of $1: 1: 1$ I. galbana, C. gracilis, and Tetraselmis suecica in the postlarval stage. The substrates with attached 2-3-month-old specimens were transferred from the rearing tanks to a flow-through downwelling system with a continuous food supply.

Specimens were sampled throughout larval, postlarval, and juvenile culture. Larvae were collected on sieves of appropriate mesh size, and settled postlarvae and juveniles were sampled from the ropes or nets, and narcotized immediately in ascending concentrations of $\mathrm{MgCl}_{2}$ (Veniot et al., 2003; Beninger and Cannuel, 2006; Cannuel and Beninger, 2006).

\section{Measurement of shell size}

Maximal shell lengths (SL) of pediveliger larvae and smaller individuals $(\leq 2.2 \mathrm{~mm}$ ) were measured using a microscope and digital camera with Lucia 4.80 image analysis software (Nikon). Maximal SL of larger specimens $(\geq 2.2 \mathrm{~mm})$ were recorded directly on scanning electron microscopy (SEM) stubs, using a dissecting microscope and ocular micrometer. Adults were measured with calipers to the nearest millimeter.

\section{Specimen processing for scanning electron microscopy (SEM)}

$\mathrm{MgCl}_{2}$-relaxed individuals were fixed in slightly hyperosmotic $2.5 \%$ glutaraldehyde in $0.2 \mathrm{~mol}^{-1}$ buffered sodium cacodylate (Beninger et al., 1995a). Samples were subsequently dehydrated in an ascending ethanol gradient and immersed in 100\% hexamethyldisilazane (HMDS) overnight. Excess HMDS was then evaporated and samples were mounted on SEM stubs, sputter-coated with gold, and observed with a JEOL 6400 scanning electron microscope (Beninger and Cannuel, 2006; Cannuel and Beninger, 2006).

\section{Terminology}

Since the size at "adulthood" is highly variable in Mytilus edulis (Seed and Suchanek, 1992), it was necessary to delimit early life stages by using characters based on gilldevelopment, which themselves corresponded to specific shell size ranges. The following terminology was adopted: "postlarvae" are individuals from settlement to $1.5 \mathrm{~mm}$ in shell length (SL) (size at which the ventral particle grooves begin to develop). "Juveniles" are individuals from $1.5 \mathrm{~mm}$ 
Table 1

Summary of gill developmental sequence in Mytilus edulis and comparison with previous studies on bivalve gill development

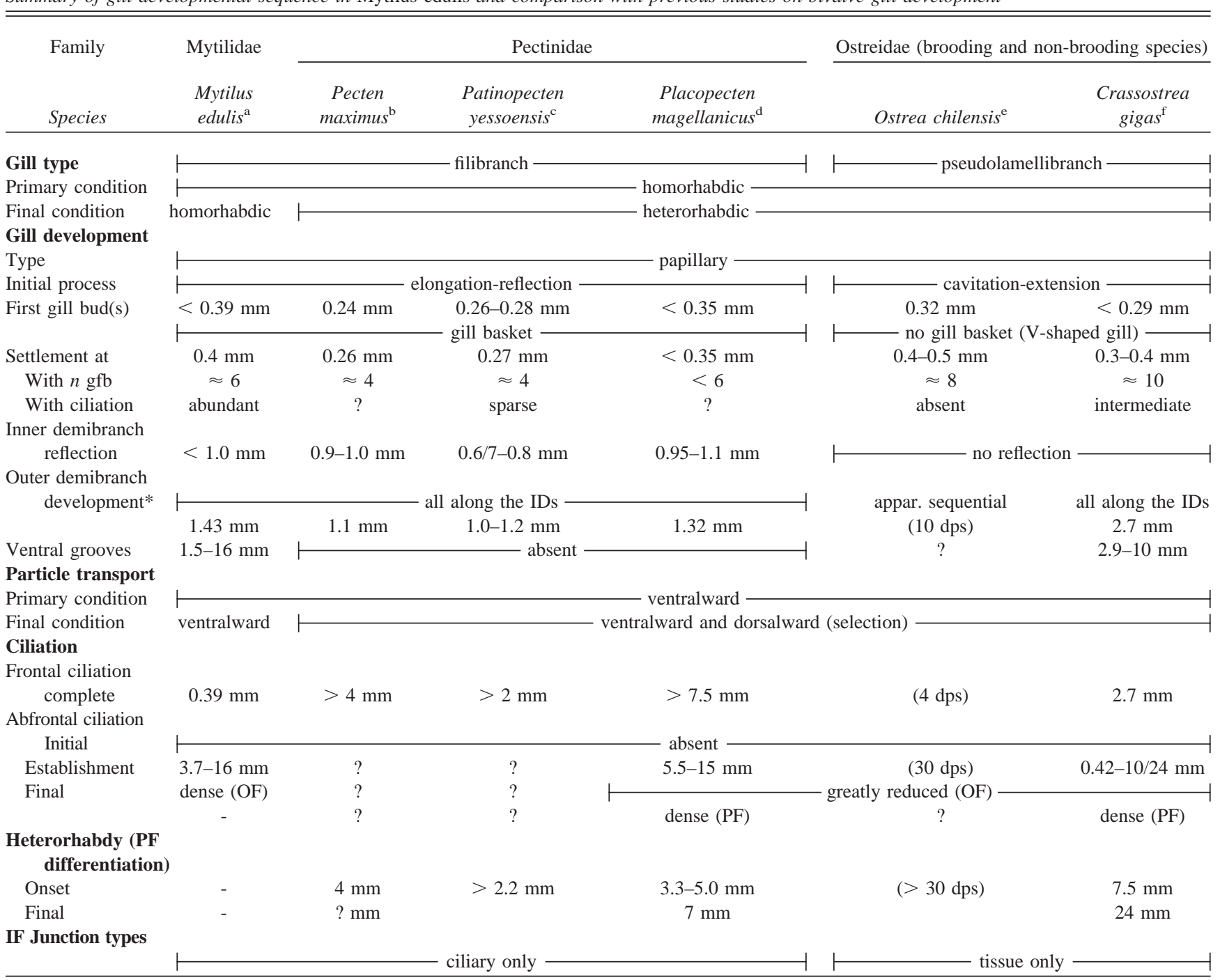

Abbreviations: appar., apparently; dps, days post-settlement; gfb, gill filaments and buds; ID, inner demibranch; IF, interfilamentar; OF, ordinary filament; PF, principal filament; * size at which outer demibranch begins development; and mode of filament addition; -, non applicable; ? data not available.

${ }^{\mathrm{a}}$ Present study; ${ }^{\mathrm{b}}$ Beninger et al., 1994; ${ }^{\mathrm{c}}$ Kingzett, 1993; ${ }^{\mathrm{d}}$ Veniot et al., 2003; ${ }^{\mathrm{e}}$ Chaparro et al., 2001; ${ }^{\mathrm{f}}$ Cannuel and Beninger, 2006

to $1.6 \mathrm{~cm}$ SL (size at which ventral particle groove development is completed; only the number and length of gill filaments continues to change thereafter). Adults are individuals $>1.6 \mathrm{~cm}$ SL.

\section{Results}

The results of the present study are summarized and compared with those of other gill types (Table 1), and detailed below.

Late pediveliger larvae: 0.39-mm SL

Gill development and growth. Pediveliger larvae at 0.39-mm mean maximum SL presented two rows of about
4-5 gill filaments and 1-2 buds on either side of the densely ciliated foot, developing anteriorly from a budding zone and ventrally from the visceral mass (Fig. 1A, B). Gill filaments were unreflected (Fig. 1B, C), and were the precursors of the descending lamellae of the future right and left inner demibranchs (IDs) (Fig. 2A). Gill filament buds, about $25 \mu \mathrm{m}$ long, differentiated in the posteriormost parts of the gill (the right and left budding zones) (Fig.1E), and elongated into gill filaments ( $\approx 90 \mu \mathrm{m}$ long for the anteriormost filament) in a posterior-to-anterior sequence (Fig. 1B).

Gill ciliation and ciliated tracts. The gill filament frontal surface was densely ciliated, with three distinct ciliary 

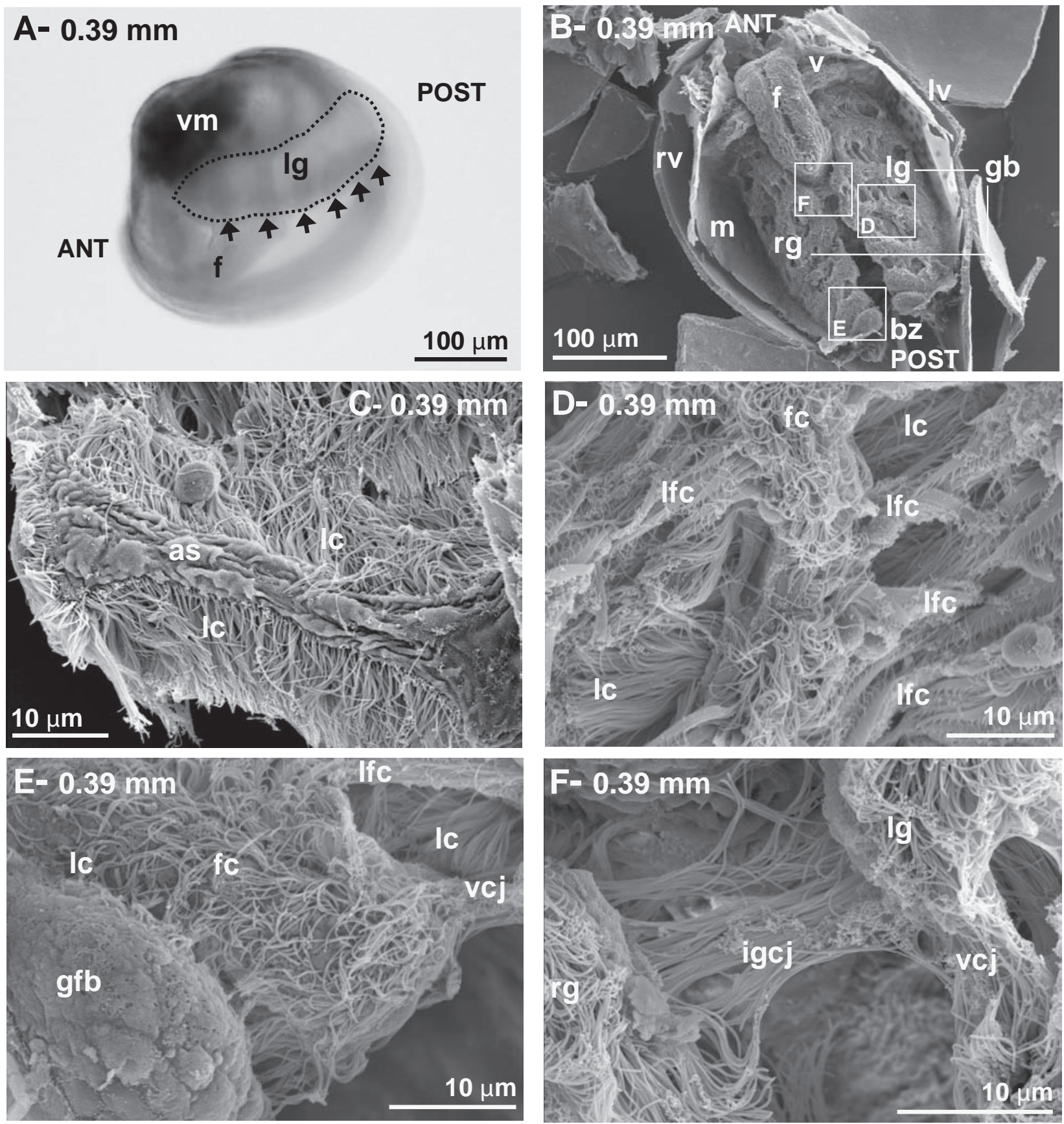

Figure 1. Mytilus edulis: late pediveliger larvae $(0.39 \mathrm{~mm})$. (A) Left lateral view of a $0.39-\mathrm{mm}$ late pediveliger larva (light microscopy). Arrows, ventral extremities of the unreflected gill filaments; dotted line, gill boundary. (B) Ventral view of a 0.39-mm pediveliger larva (SEM). Boxes D, E, and F: regions shown in detail in the corresponding micrographs. (C) Abfrontal view of a gill filament, showing unciliated surface. (D) Frontal view of a gill filament. (E) Detail of the right budding zone. (F) Detail of the ventral extremities of two opposing gill filaments (mid-gill). Note interlocking ciliated junctions. ANT, anterior; as, abfrontal surface; bz, budding zones; $\mathrm{f}$, foot; fc, frontal cilia; gb, gill basket formed by the left and right gills; gfb, gill filament bud; igcj, inter-gill ciliary junction; lc, lateral cilia; lfc, latero-frontal cirri; lg, left gill; lv, left valve; m, mantle; POST, posterior; rg, right gill; rv, right valve; v, velum (retracted); vcj, ventral (terminal) ciliary junction; vm, visceral mass.

types: lateral cilia $(\approx 12-14 \mu \mathrm{m})$, simple frontal cilia $(\approx 4.2-6.2 \mu \mathrm{m})$ in tracts about $7.5-9 \mu \mathrm{m}$ wide, and compound latero-frontal cirri $(\approx 10.5-14 \mu \mathrm{m})$ (Fig. 1D). Each latero-frontal compound cirrus was composed of two rows of 15 to 19 component simple cilia. The ventral extremities of gill filaments were also abundantly ciliated with simple 


\section{Dorsal}
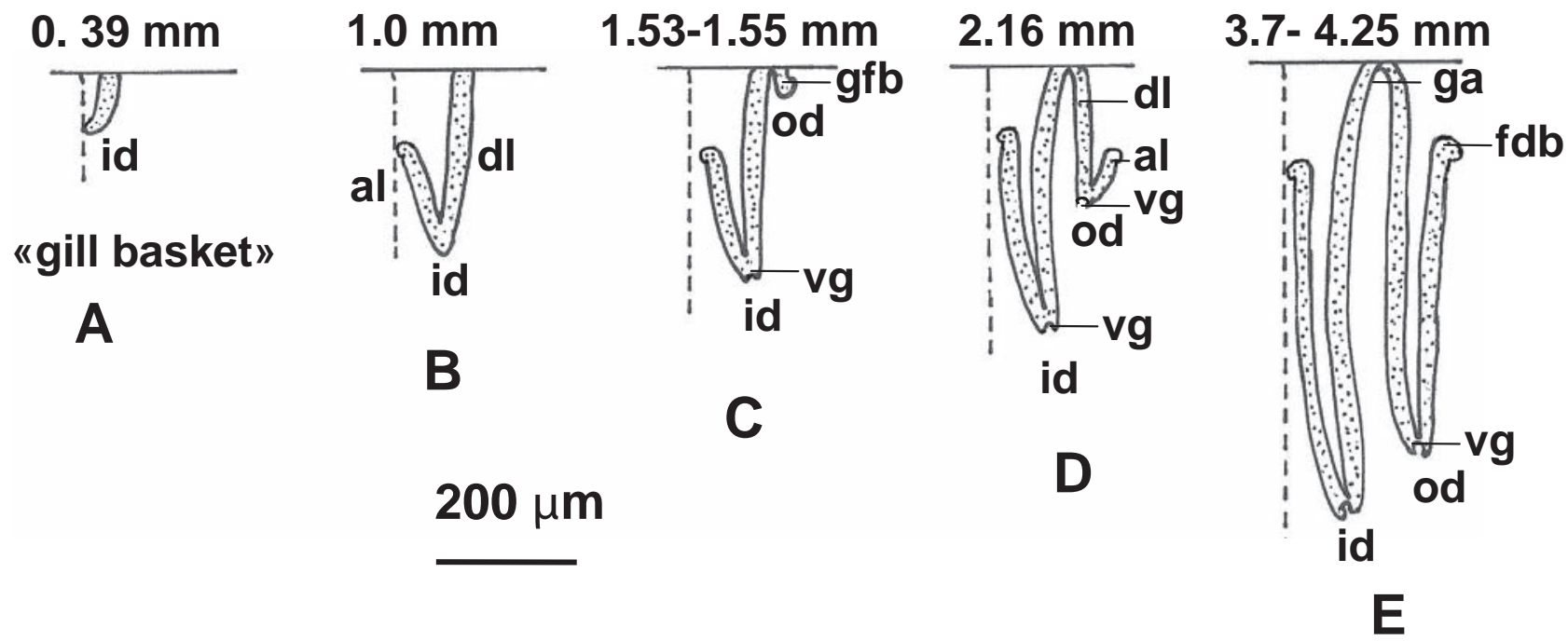

\section{Ventral}

Figure 2. Mytilus edulis: diagram of gill ontogeny. Dotted line, antero-posterior axis of symmetry. (A) 0.39-mm late pediveliger larvae. (B) 1.0-mm postlarvae. (C) 1.53-1.55-mm postlarvae. (D) 2.16-mm postlarvae. (E) 3.7-4.25-mm postlarvae. Note process of elongation-reflection in A-D; appearance of outer demibranch in C-E. al, ascending lamella; dl, descending lamella; fdb, fused dorsal bend; ga, gill arch; gfb, gill filament bud; id, inner demibranch; od, outer demibranch; vg, ventral groove.

cilia 5-7 $\mu \mathrm{m}$ in length. In contrast with the other parts of the gill filament, the abfrontal surface was unciliated at this stage (Fig. 1C). The most-recently differentiated gill buds were unciliated, except on their anterior side where short lateral cilia were observed (Fig. 1E).

Ciliary and tissue junctions. In about half of the specimens, posterior to the foot, inter-gill ciliary junctions composed of interlocking cilia joined each pair of opposite gill filaments (Fig. 1B, F), whereas ventral ciliary junctions joining the adjacent filaments of each ID were present in all specimens (Fig. 1E, F). Both joined and non-joined filaments of the right and left gills were curved inward, with the corresponding ventral extremities in close contact, thus forming a gill basket (Figs. 1B; 2A). The gill basket temporarily divided the pallial cavity into suprabranchial and infrabranchial chambers.

Other observations. The retracted velum was still visible at this stage (Fig. 1B).

\section{Postlarvae: 1-mm SL}

Gill development and growth. About 15-16 gill filaments and buds were observed on each ID in 1-mm-SL postlarvae (Fig. 3A, B). These gill filaments were reflected, forming the descending and ascending lamellae of the IDs of the left and right gills (Figs. 3A, B, C; 2B), via an elongation- reflection process. Newly differentiated gill filaments in 1-mm postlarvae were reflected from the start, and the distal-most extremities of adjacent filaments were fused (fused dorsal bends; Fig. 3C). Gill development at this stage was thus substantially different from that in the $0.39-\mathrm{mm}$ stage described above.

Gill ciliation and ciliated tracts. The frontal surfaces of both the descending and ascending gill filaments were densely ciliated with the three previously described ciliary types: frontal cilia $(\approx 6.0-8.8 \mu \mathrm{m})$, lateral cilia $(\approx 11.7-17.5 \mu \mathrm{m})$, and latero-frontal cirri $(\approx 13.1-17.5 \mu \mathrm{m})$. Latero-frontal cirri were composed of 16-20 opposing pairs of cilia. The abfrontal surfaces were still unciliated at this stage.

Ciliary and tissue junctions. The dorsal extremities of existing ascending gill filaments were fused and densely ciliated (fused dorsal bends; Fig. 3C, D) with about 2.5-5.5 $\mu \mathrm{m}$ short simple cilia.

Other observations. The velum had totally regressed at this stage, and labial palp primordia began to differentiate around the mouth (Fig. 3A, B).

Postlarvae: 1.43- to 1.55-mm SL

Gill development and growth. The formation of the outer demibranchs (ODs) began during this period and constitues 

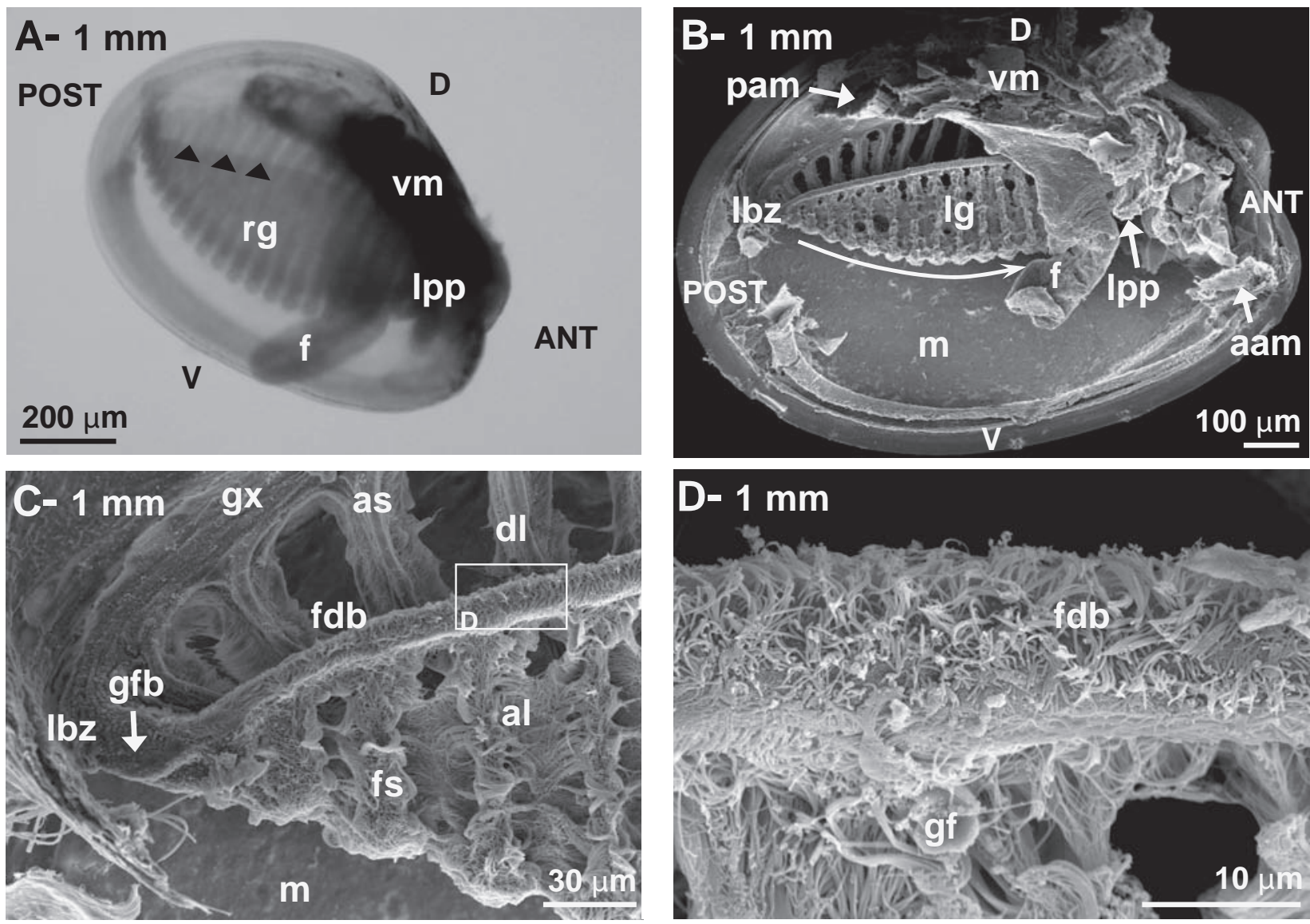

Figure 3. Mytilus edulis: postlarvae $(1 \mathrm{~mm})$. (A) Right lateral view of a 1-mm postlarva (light microscopy). Arrows, dorsal boundary of the ascending lamella (reflected gill filaments). (B) Lateral view of a 1-mm postlarva (right valve, mantle, and gill removed; SEM). Thin curved arrow, antero-posterior sequence of gill development. (C) Detail of the left budding zone in a 1-mm postlarva (SEM). Box D, region shown in detail in the corresponding micrograph. (D) Detail of the fused ascending extremity in the dorsal part of the ascending lamella. aam, anterior adductor muscle; al, ascending lamella; ANT, anterior; as, abfrontal surface; D, dorsal; dl, descending lamella; f, foot; fdb, fused dorsal bend; fs, frontal surface; gf, gill filament; gfb, gill filament bud; gx, gill axis; lbz, left budding zone; lg, left gill; lpp, labial palp primordia; m, mantle; pam, posterior adductor muscle; POST, posterior; rg, right gill; V, ventral; vm, visceral mass.

another major change in gill development. From 1.43-mm SL onward, the ODs began to develop simultaneously along the IDs at the gill-mantle junction, first as rows of gill filament buds, except in the most anterior part of the preexisting IDs where no OD filament buds were observed (as shown in a $1.53-\mathrm{mm}$ specimen in Fig. 4A; Fig. 2C). Filament number in both IDs increased compared to the previous developmental stage: about 22 gill filaments in 1.53-mm postlarvae (Fig. 4A). The number of gill filaments in the ODs $(\approx 16$ in $1.53-\mathrm{mm}$ specimens $)$ of postlarvae 1.38 -mm SL (not shown) was thus somewhat lower than those of the IDs (difference of $\approx 8$ gill filaments). In contrast to the situation prior to the $1.43-\mathrm{mm}$ shell size, each new gill filament bud gave rise to both ID and OD simultaneously (Fig. 4B). After a slight elongation, the recently developed OD gill filaments reflected almost immediately in $1.55-\mathrm{mm}$ specimens (Figs. 4C, D; 2C), with tissue fusion at the distal-most extremities as in the IDs. The cleft between the parallel lines of buds and filaments also marked the location of the future gill arch (Figs. 4A, C; 2C, E).

Gill ciliation and ciliated tracts. Frontal cilia were about 6.6-9.2 $\mu \mathrm{m}$ long, latero-frontal cilia were about 12.5-19.3 $\mu \mathrm{m}$ long, and lateral cilia were about 9.5-15 $\mu \mathrm{m}$ long (not shown) in the ID filaments. At this stage, two ventral particle grooves began to develop, first as shallow grooves at the ventral extremities of the IDs in $1.53-\mathrm{mm}$ postlarvae (Fig. 4C).

\section{Postlarvae: $2.16-$ to $2.74-\mathrm{mm} S L$}

Gill development and growth. In 2.16- to 2.74-mm-SL postlarvae, new gill filaments were added to both the IDs and ODs as described above for the 1.43-1.55-mm-SL postlar- 
vae (Fig.4E). The IDs and ODs of 2.74-mm specimens presented about 38-39 and 30 gill filaments, respectively. The rapid elongation-reflection process described above for the $1.43-1.55 \mathrm{~mm}$ postlarvae was evident at this stage (Figs. $4 \mathrm{E} ; 2 \mathrm{D})$.

Gill ciliation and ciliated tracts. Gill-filament ciliation comprised the previously described cilia and cirri: frontal cilia $(\approx 7-10 \mu \mathrm{m})$, latero-frontal cirri $(\approx 15-20 \mu \mathrm{m})$, and lateral cilia $(\approx 10-14.5 \mu \mathrm{m})$. Latero-frontal cirri, composed of 19-22 opposing pairs of cilia, were regularly spaced at 2-3 $\mu \mathrm{m}$ on either side of the frontal ciliated tract. The abfrontal surface remained unciliated at this stage. One shallow ventral groove was observed on each demibranch, except on the $8-10$ most recently differentiated gill filaments and buds (Fig. 4E).

Ciliary and tissue junctions. Non-terminal interfilamentar ciliary junctions were first observed, both on the IDs and ODs, in a $2.34-\mathrm{mm}$ specimen (Fig. $4 \mathrm{~F}$, G, in a $2.74-\mathrm{mm}$ specimen), connecting two adjacent gill filaments.

\section{Postlarvae: 3.7- to 4.25-mm SL}

Gill development and growth. The number and length of gill filaments increased in 3.7-mm-SL postlarvae, with about 60-63 and about 51-53 filaments in the IDs and ODs, respectively (Figs. 5A; 2E).

Gill ciliation and ciliated tracts. The fused dorsal bends of the IDs and ODs were densely ciliated, with about 3-5- $\mu \mathrm{m}$ short simple cilia on the surface corresponding to the area of contact between the fused dorsal bends and the mantle (as in living, non-dissected specimens), and about $12-\mu \mathrm{m}$-long simple cilia (Fig. 5A) on their ventral face. Gill filament ciliation was invariably composed of frontal cilia $(\approx 7-9$ $\mu \mathrm{m}$ long) on an about 8.5-12.2 $\mu \mathrm{m}$ wide frontal tract, latero-frontal cirri $(\approx 17 \mu \mathrm{m})$ and lateral cilia $(\approx 11-17 \mu \mathrm{m})$ (not shown). Each latero-frontal cirrus was formed from 22 to 24 opposing pairs of simple cilia, and the inter-cirral distance was about $2 \mu \mathrm{m}$. At this stage, scattered clumps of short simple cilia $(\approx 3.5-5.4 \mu \mathrm{m}$ long) were observed in a band about 2.5-3 $\mu \mathrm{m}$ wide on the abfrontal surface of each gill filament (Fig. 5B). On the ventral extremities of the IDs and ODs, the ventral grooves were deeper in the $4.25-\mathrm{mm}$ specimen (Fig. 5C), compared with the 2.16-mm specimen previously described.

Ciliary and tissue junctions. The number of non-terminal ciliary junctions increased concomitantly with gill filament elongation, delimiting ostia about 155-190 $\mu \mathrm{m}$ long (not shown).
Postlarvae: 9.75-mm SL

Gill development and growth. The number of gill filaments increased in $9.75-\mathrm{mm}$ postlarvae ( $>130$ for the IDs; Fig. 5D).

Gill ciliation and ciliated tracts. Gill filament ciliation consisted of about 7.5-8.6- $\mu \mathrm{m}$ frontal cilia, about $16.5-20-\mu \mathrm{m}$ latero-frontal cirri, about $12.8-16.7-\mu \mathrm{m}$ lateral cilia, and about 2.8-5.2- $\mu \mathrm{m}$ abfrontal cilia (Fig. 5E), the latter now being almost continuously distributed along the abfrontal surface. At this stage, the abfrontal ciliary band was about 2.6-5 $\mu \mathrm{m}$ wide (Fig. 5E), whereas the frontal ciliary tract was about 11.5-15.4 $\mu \mathrm{m}$ wide (Fig. 5-F). Ventral grooves, both in the IDs and ODs, were deeper and more enclosed than those in the 4.25-mm stage (Fig. 5F).

Ciliary and tissue junctions. The filaments presented about eight transverse rows of non-terminal interfilamentar ciliary junctions, delimiting ostia 160 to $250 \mu \mathrm{m}$ long. A second junctional type was first observed at this stage: interlamellar tissue junctions joining the descending and ascending lamellae of a demibranch, located in the ventral half of the demibranch (Fig. 5D).

Juveniles-1.55- to 1.60-cm-SL, and adults-1.80-cm SL

Gill development and growth. Throughout this range of specimens, the right and left budding zones resembled those seen in an adult in $1.75-\mathrm{cm}$ specimens, with a single bud giving rise first to a transition zone and then to both ID and OD (Fig. 6D).

Gill ciliation and ciliated tracts. In $1.55-\mathrm{cm}$ juveniles, gill filament ciliation remained unchanged, comprising about 6.3-10.5- $\mu \mathrm{m}$ frontal cilia, about $13.8-22-\mu \mathrm{m}$ latero-frontal cirri, and about 11-14.7- $\mu \mathrm{m}$ lateral cilia (not shown). Abfrontal cilia, about 4.1-5.7 $\mu \mathrm{m}$ long, appeared to be denser than in the previous stage (Fig. 6A). The frontal ciliary tract was about 10.6-14.5 $\mu \mathrm{m}$ wide, and the abfrontal ciliated band was about $4.5 \mu \mathrm{m}$ wide. From this stage $(1.55 \mathrm{~cm})$ forward, ventral grooves were totally enclosed: i.e., visible from the exterior only as the appression of the inner and outer filament extremities. They were observed in a fractured gill extremity of a $1.62-\mathrm{cm}$ specimen (not shown; groove dimensions: $12-13 \mu \mathrm{m}$ wide, $21-22 \mu \mathrm{m}$ deep), indicating the completion of ventral groove development. In a $1.80-\mathrm{cm}$ juvenile, the right and left gill arches (between the right and left ID and OD of each gill) presented both simple and apparently grouped cilia about $8-13 \mu \mathrm{m}$ in length (Fig. 6C).

Ciliary and tissue junctions. Ostia about 140-320 $\mu \mathrm{m}$ long were delimited by the interfilamentar ciliary junctions. Smaller ostia of variable sizes (about $85-100,40-70$, and 

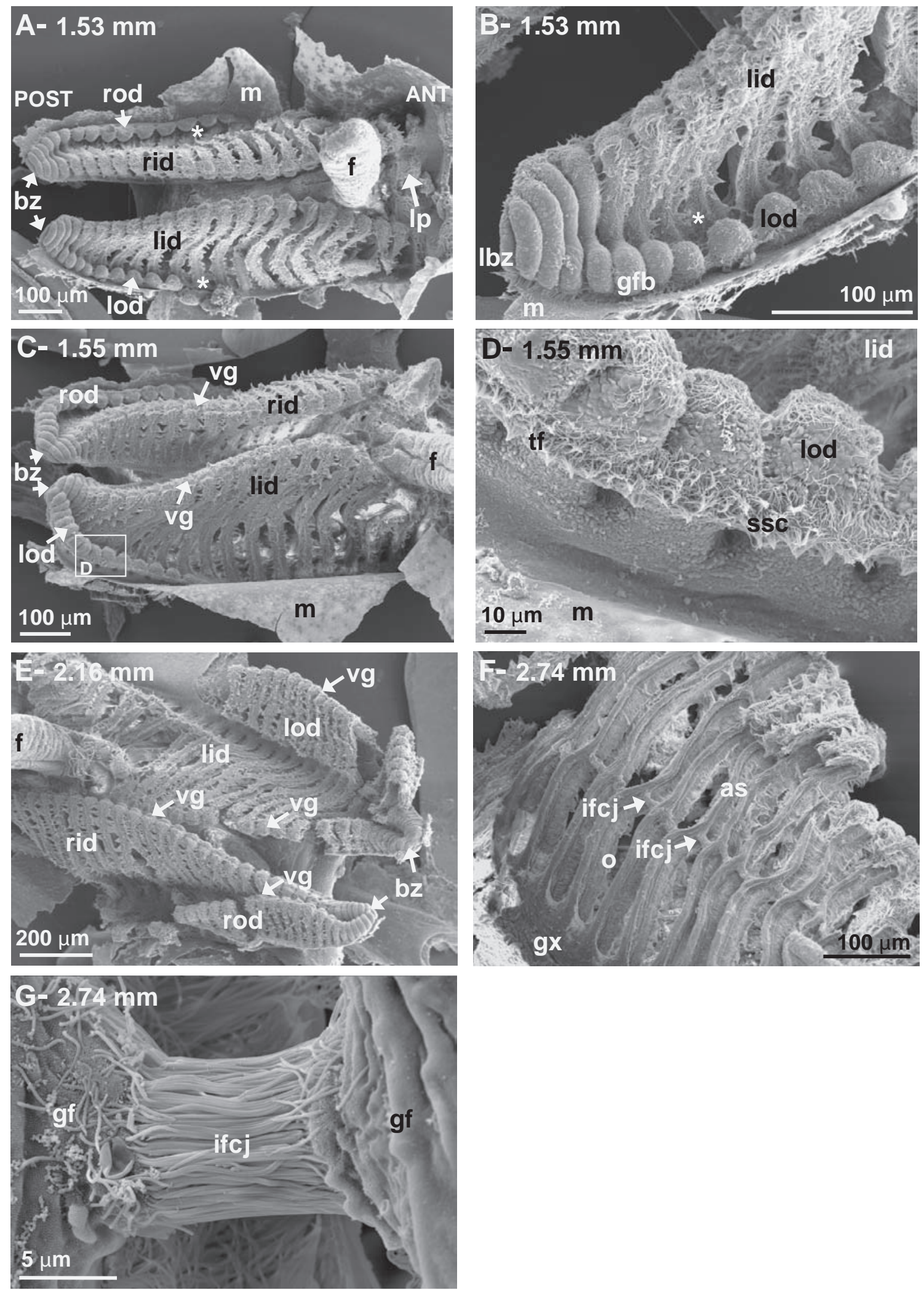
4.5-26 $\mu \mathrm{m})$ were also occasionally observed near the ventral grooves, near the gill axis, and in the mid-gill area, respectively (Fig. 6B, in a $1.62-\mathrm{cm}$ specimen).

\section{Adult specimens: $5.3-\mathrm{cm}$ SL}

Gill development and growth. Adult mussels presented the homorhabdic filibranch gill characteristic of the Mytilidae.

Gill ciliation and ciliated tracts. Gill filaments presented the ciliary types previously described in younger specimens: about 7.3-9.4- $\mu \mathrm{m}$ frontal cilia, about $13-18.3-\mu \mathrm{m}$ laterofrontal cirri, about 11.9-15.6- $\mu \mathrm{m}$ lateral cilia (Fig. 6E), and about 4.5-5.3- $\mu \mathrm{m}$ abfrontal cilia. Between 1.55- and 5.3-cm SL, frontal and abfrontal ciliary tracts were enlarged, and were about $20 \mu \mathrm{m}$ and about $6.3-10 \mu \mathrm{m}$ wide in adults, respectively (Fig. 6E, F). Abfrontal ciliation was more extensive near interlamellar tissue junctions and interfilamentar ciliary junctions (Fig. 6G, inset). As in the previously described developmental stage, ventral particle grooves were deep and fully enclosed (Fig. 6H). Simple and apparently grouped cilia ( 8 to $14.5 \mu \mathrm{m}$ ) were observed on gill arches, as in the 1.55-1.75-cm juveniles (not shown).

Gill filaments were also elongated along the frontalabfrontal axis $(\approx 125 \mu \mathrm{m})$ and a wide sub-lateral surface separated the frontal, latero-frontal, and lateral ciliations from the abfrontal ciliation. This sublateral surface was unciliated except for few very sparse cilia (Fig. 6F).

Ciliary and tissue junctions. Abfrontal, diagonally arranged interlamellar tissue junctions were located in the ventral half of the gill lamellae (Fig.6G). Ostia delimited by two interfilamentar ciliary junctions were about 180-260 $\mu \mathrm{m}$ long (Fig. 6G).

\section{Discussion}

The present study documents the complete gill development of Mytilus edulis, which comprises four major developmental stages: (1) transition from velum to gill basket at metamorphosis, (2) reflection of the inner demibranchs (IDs) and transition from a gill basket to a $\mathrm{V}$-shaped gill, (3) formation of the outer demibranchs (ODs) and transition from a V- to a W-shaped gill, and (4) formation of the ventral grooves and concomitant acquisition of dense abfrontal ciliation. We also report on the formation of gill junctions, as well as the acquisition of frontal ciliation, leading to the final adult functioning gill. These findings are summarized in Table 1, where they are compared with previous observations of other gill types and species.

\section{Gill development and growth}

After the pediveliger gill basket stage, gill filament elongation was rapidly followed by reflection, and subsequent formation of the ascending lamellae, corresponding to the $\mathrm{V}$-shape stage of each gill, as previously described for $M$. edulis and in the heterorhabdic filibranch Pectinidae (Rice, 1908; Bayne, 1971; Kingzett, 1993; Beninger et al., 1994; Veniot et al., 2003). This process of elongation-reflection contrasts with the "cavitation-extension" process of gill development described for the pseudolamellibranchs Crassostrea gigas (Cannuel and Beninger, 2006) and Ostrea chilensis (deduced from the work of Chaparro et al., 2001) where perforation in the rudimentary gill filament and subsequent ventralward elongation of this developing filament were observed (see Cannuel and Beninger, 2006 for details). Gill filaments in the homorhabdic filibranch Mytilidae and heterorhabdic filibranch Pectinidae thus elongate via a process radically different from that seen in the filaments of the pseudolamellibranch Ostreidae (Table 1). The process of filament elongation has not yet been clearly described in the fourth and dominant gill type, the eulamellibranch, which, like the peudolamellibranch, is characterized, in the adult, by tissular fusion of the dorsal bends with the mantle, lateral to the base of the descending lamella. As a potential taxonomic and phylogenetic character, this is obviously an important subject for future investigation.

Delayed development of the ODs, documented here for M. edulis, appears to be the rule in bivalves (Lacaze-Duthiers, 1856; Jackson, 1890; Quayle, 1952; Raven, 1958; D'Asaro, 1967; Caddy, 1969; Kingzett, 1993; Baker and Mann, 1994; Beninger et al., 1994; Korniushin, 1996, 1997; Chaparro et al., 2001; Neumann and Kappes, 2003; Veniot et al., 2003; Cannuel and Beninger, 2006; Table 1). Fur-

Figure 4. Mytilus edulis: postlarvae (1.53 to $2.74 \mathrm{~mm})$. (A) Ventral view of a 1.53-mm postlarva (shell and mantle removed). Asterisk (*), future gill arches. (B) Detail of the left budding zone in a 1.53-mm postlarva. Asterisk (*), future left gill arch. (C) Ventral view of a 1.55-mm postlarva (shell and mantle removed). Box D, region shown in detail in the corresponding micrograph. (D) Detail of the left outer demibranch (OD) in a 1.55-mm postlarva. Note near-immediate reflection of outer demibranch filaments after elongation from bud. (E) Ventral view of a 2.16-mm postlarva. (F) Abfrontal view of an inner demibranch (ID) (descending lamella) in a 2.74-mm postlarva (ascending lamella removed). (G) Detail of an interfilamentar ciliary junction in a 2.74-mm postlarva (abfrontal view). ANT, anterior; as, abfrontal surface; bz, budding zones; f, foot; gx, gill axis; gf, gill filament; gfb, gill filament bud; ifcj, interfilamentar ciliary junction; lbz, left budding zone; lid, left ID; lod, left OD; lp, labial palps; m, mantle; o, ostium; POST, posterior; rid, right ID; rod, right OD; ssc, short simple cilia; tf, tissue fusion; vg, ventral groove. 

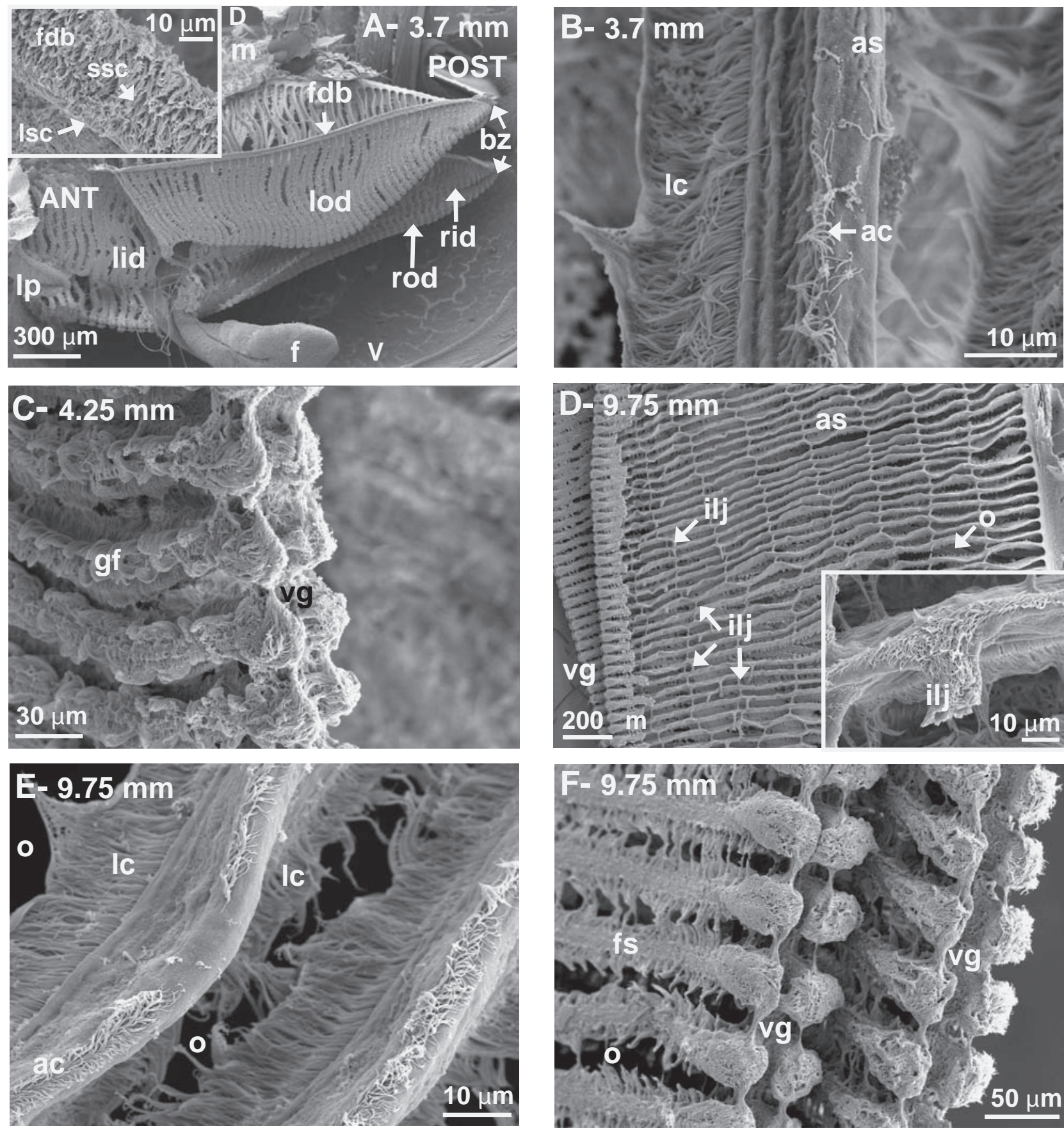

Figure 5. Mytilus edulis: postlarvae (3.7 to $9.75 \mathrm{~mm}$ ). (A) Left lateral view of a $3.7-\mathrm{mm}$ postlarva (shell and mantle removed); inset, detail of the fused extremities of the ascending lamellae in the dorsal part of the OD. (B) Detail of the abfrontal surface of a gill filament in a $3.7-\mathrm{mm}$ postlarva. (C) Latero-ventral view of a ventral groove in a 4.25-mm postlarva. Note formation of ventral particle groove. (D) Abfrontal view of the descending lamella (reflected/ascending lamella removed) of the left gill ID in a $9.75-\mathrm{mm}$ postlarva; inset, detail of an interlamellar junction. (E) Abfrontal view of two gill filaments in a 9.75-mm postlarva. (F) Latero-ventral view of the ventral extremities of the right gill in a $9.75-\mathrm{mm}$ postlarva. Ventral particle groove no longer visible, having been occluded by the overgrown edges of the ventral filament extremities. ac, abfrontal cilia; as, abfrontal surface; bz, budding zones; D, dorsal; f, foot; fdb, fused dorsal bend; fs, frontal surface; gf, gill filament; ilj, interlamellar junction (sectioned during specimen dissection); lc, lateral cilia; lid, left ID; lod, left OD; lp, labial palps; lsc, long simple cilia; m, mantle; o, ostium; rid, right inner demibranch; rod, right outer demibranch; ssc, short simple cilia; V, ventral; vg, ventral groove. 
thermore, in contrast to the sequential filament development from the budding zone, seen in the IDs, filament development of the ODs proceeded from buds appearing simultaneously along the gill axis, alongside the ID filaments. This appears to be the general rule in the gill types studied to date, with the exception of the brooding pseudolamellibranch $O$. chilensis (Table 1); further investigation of this aspect would be welcome.

After the onset of gill differentiation, ID reflection, and OD formation and reflection, subsequent growth of the gill with increasing body size in juveniles and adults implies both constant activity of the budding zones and gill tissue proliferation in the gill filaments (Leibson and Movchan, 1975; Neumann and Kappes, 2003). The budding zones attain their final functioning state after OD development, with one gill filament bud giving rise to both ID and OD.

\section{Gill ciliation and ciliated tracts}

Gill filaments were characterized by dense ciliation from the onset of gill development in M. edulis: frontal and lateral cilia, as well as latero-frontal cirri, were observed from the onset of gill filament differentiation. This has also been reported in another homorhabdic filibranch, Codakia orbicularis (Gros et al., 1998, mis-reported as a eulamellibranch). In contrast, the latero-frontal cilia of pseudolamellibranchs were first observed in 2.70-mm Crassostrea gigas juveniles (Cannuel and Beninger, 2006), and at 4 days post-settlement in $O$. chilensis (unknown shell length; Chaparro et al., 2001) (Table 1). Similarly, among heterorhabdic filibranchs, 2-mm Patinopecten yessoensis, 4-mm Pecten maximus, and 7.5-mm Placopecten magellanicus specimens lack the single row of latero-frontal cilia typically found in pectinid adults (Atkins, 1938; Kingzett, 1993; Beninger et al., 1994; Veniot et al., 2003). The precocious appearance of the latero-frontal cirri in homorhabdic filibranchs, together with the probable particle capture inefficiency of the gill basket (Beninger et al., 1994; Veniot et al., 2003), suggests that they are "pre-positioned" for functionality in later stages of gill development.

\section{Functional and ecological implications}

The successive developmental changes in gill structure documented here suggest consecutive modes of particle capture, transport, or both, and variations in associated efficiencies throughout gill development. In pediveliger larvae and young postlarvae, the gill basket presumably functions as described for Pectinidae of the same developmental stage (Kingzett, 1993; Beninger et al., 1994; Veniot et al., 2003). Although doubtless important in establishing the dominant currents in the pallial cavity, the gill basket structure has been proposed to be inefficient in particle capture in P. maximus (Beninger et al., 1994) and P. magellanicus postlarvae (Veniot et al., 2003). This hypothesis is sup- ported by the sporadic and uncoordinated cilia movements on the gill filaments of pediveligers of M. edulis (Bayne, 1971). Such inefficiency in particle capture and processing suggests reliance on alternative trophic mechanisms, such as utilization of dissolved organic matter (Fankboner and De Burgh, 1978; Rice et al., 1980; Manahan, 1983, 1990; Wotton, 1988; Marshall and Lee, 1991; Hawkins and Bayne, 1992), and pedal feeding (Ó Foighil et al., 1990; Reid, 1991; Reid et al., 1992; Kingzett, 1993; Beninger et al., 1994; Veniot et al., 2003). Indeed, elaboration of a complex system for particle capture and processing at this stage would probably be superfluous for the small larvae.

Gill currents and subsequent feeding ability were observed within 2 days of metamorphosis in M. edulis (Bayne, 1971; Lutz and Kennish, 1992), corresponding to the early appearance of frontal, latero-frontal, and lateral filament ciliation reported in the present study. The gill development stage of settling M. edulis and C. gigas appears to be more advanced than in previously studied larval and postlarval bivalves (Table 1; Hodgson and Burke, 1988).

Further reflection of the IDs resulted in left and right V-shaped gills, capable of oralward particle transport, both on the ventral and dorsal ciliated tracts, as observed by Stasek (1962). Concomitant disorganization of the gill basket and development of the ODs greatly increased the area of both the particle processing and respiratory surfaces; simultaneously, gill filaments also grew in the frontal-abfrontal direction, further increasing respiratory surface. These rapid morphological changes are probably responsible for the changes in rates of filtration and respiration observed in 1- to 4-mm M. edulis postlarvae, and attributed to non-isometric growth of the gills (Riisgård et al., 1980). Progressive acquisition of ventral particle grooves (Table 1) provides routes of semi-enclosed anteriorward mucus-particle transport, preventing resuspension of captured particles in the pallial cavity (Foster-Smith, 1975; Newell et al., 1989).

Gill filament frontal ciliation in M. edulis was here shown to be nearly identical from the pediveliger to the adult stages, whereas the frontal, and then abfrontal, tract widths grew throughout gill development. The latero-frontal cirri observed from the pediveliger stage were disproportionately large compared to frontal tract width, such that they must either overreach the frontal tract at the end of the effective stroke or present reduced stroke amplitudes. Particle capture mechanisms and efficiencies are thus probably different from those of adult mussels (Dral, 1967; Moore, 1971; Owen, 1974; Owen and McCrae, 1976; Møhlenberg and Riisgård, 1978; Riisgård et al., 1996; Silverman et al., 1996, 1999, 2000; Gosling, 2003). Indiscriminate particle transport, characteristic of adult mussels (Beninger et al., 1993; Ward et al., 1991, 1993; Beninger and St-Jean, 1997) is morphologically possible in about 2-mm postlarvae, which 

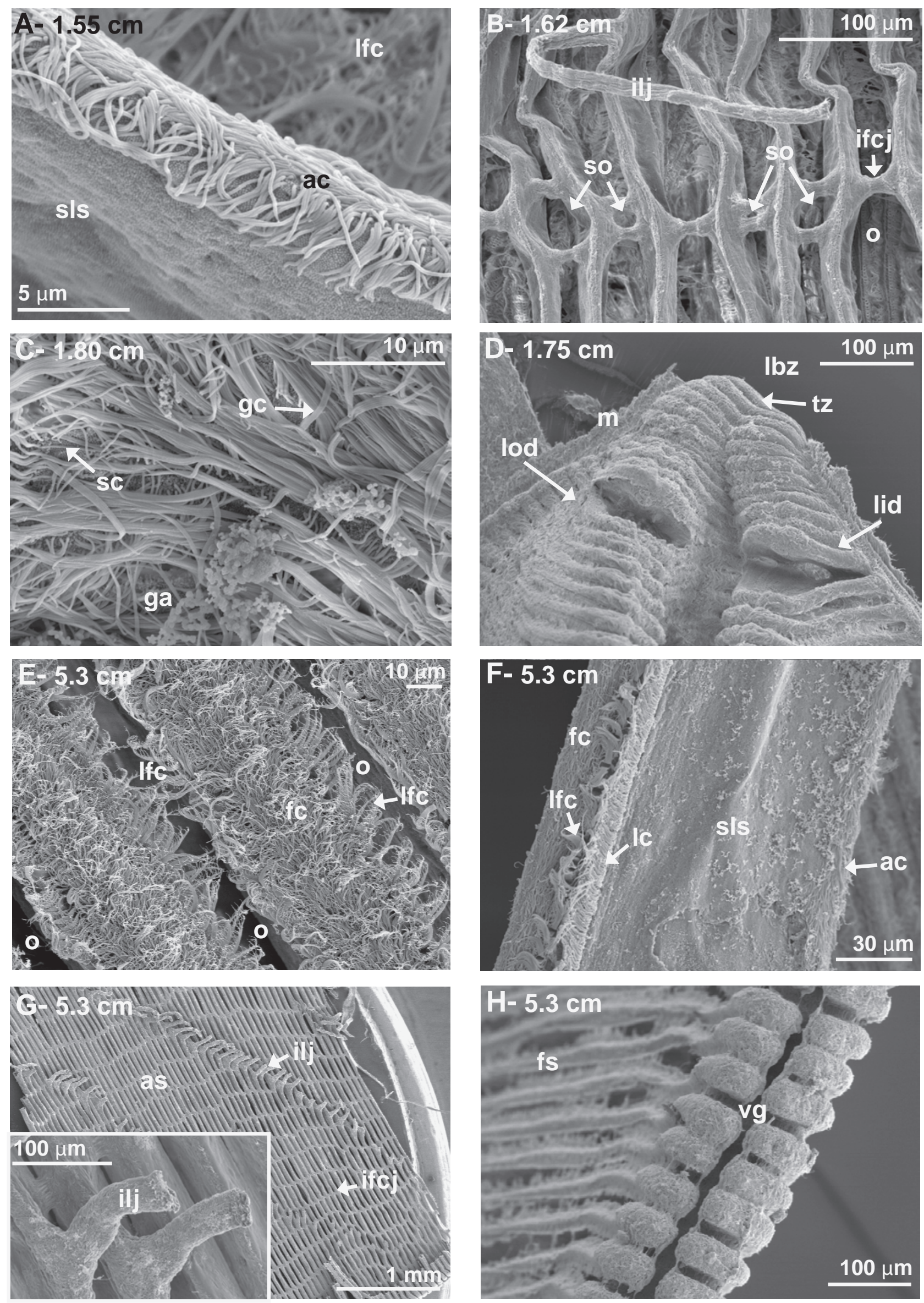
present the basic features of the adult gill and in which the ventral particle groove has begun to develop.

The function, if any, of the dense abfrontal ciliation of adult $M$. edulis gills (compared to the relative absence of such cilia in most other bivalve gills) has been debated in recent years. Originally thought to participate in maintaining current flow in the pallial cavity (Jones et al., 1990, 1992; Jones and Richards, 1993), it was also suggested to be purely vestigial (Beninger and Dufour, 2000; Dufour and Beninger, 2001; Table 1). Its acquisition at 3.7-mm shell length belies the latter interpretation and lends support to the original hypothesis: the abfrontal ciliation probably results in increased water pumping efficiency and may be correlated with the development of the ventral grooves, which protect the captured particles from being resuspended by the pallial currents (Table 1).

\section{Ciliary and tissue junctions-maintenance of gill integrity}

Various ciliary and tissular junctions are involved in interfilamentar and interlamellar cohesion throughout gill development in M. edulis (Sunila and Lindström, 1985; Beninger et al., 1988; Table 1). The gill basket is maintained by both interfilamentar and inter-gill ciliary junctions, as previously described in the Pectinidae $P$. yessoensis and P. magellanicus (Kingzett, 1993; Veniot et al., 2003).

After reflection of the gill filaments and growth of the ODs, dorsal bends were shown to be abundantly ciliated with short simple cilia in M. edulis, both on the IDs and ODs. Such cilia have been shown to interlock with those of the opposing left and right demibranchs in the V-shape stage, and also with those of the mantle in the W-shape stage in P. yessoensis (Kingzett, 1993), separating the infrabranchial and suprabranchial cavities. The band of short simple cilia observed on the mantle surface, just dorsal to the rejection tract, is ideally positioned to interlock with those of the gill dorsal bends (Beninger et al., 1995b, 1999), and to function similarly to the shunt mechanism described for the heterorhabdic filibranch P. magellanicus (Beninger et al., 1992).

Interlamellar junctions were the only tissular junctions observed in the present study, both in their relaxed and contracted states, and were organized in diagonal rows on the abfrontal filament surfaces in the later developmental stages, as previously reported for adults (Atkins, 1931; Dufour and Beninger, 2001). This contractile system may be involved in the shunt mechanism, via shortening and subsequent detachment of the dorsal bends from the mantle surface.

\section{Evolutionary implications}

Although the data concerning gill ontogeny in bivalves are still rather scarce, two superficially similar systems have been described previously: the heterorhabdic filibranch and the heterorhabdic pseudolamellibranch. The present report of gill ontogeny in the homorhabdic filibranch M. edulis allows comparison with these systems (Table 1). A major difference emerges in the earliest stage of gill development: the gill basket is common to both heterorhabdic and homorhabdic filibranch gills, but is absent in the pseudolamellibranch gill (Table 1).

The filibranch homorhabdic gill of adult $M$. edulis is considered to be the pleisiomorphic condition from which the other gill types evolved (Beninger and Dufour, 2000; Dufour and Beninger, 2001). The presence of an abfrontal filament ciliation, observed in adult $M$. edulis, is considered pleisiomorphic for bivalves (Salvini-Plawen and Steiner, 1996; Beninger and Dufour, 2000; Giribet and Wheeler, 2002); reduction in this abfrontal ciliation in other gill types is considered apomorphic (Beninger and Dufour, 2000). The abundant abfrontal ciliation seen in $M$. edulis adults could thus either indicate their pleisiomorphic character in this primitive autobranch gill type (Beninger and Dufour, 2000), or correspond to a contemporary function, such as the contribution to water pumping in the pallial cavity (Jones et al., 1990, 1992; Jones and Richards, 1993). Quite unexpectedly, the results of the present study show that the abundant abfrontal ciliation of $M$. edulis is a feature acquired at a relatively late developmental stage $(3.7 \mathrm{~mm})$, at variance with the hypothesis of a persistent pleisiomorphic state and supporting the interpretation of a contemporary function. Conversely, the dense ciliation of both the gill

Figure 6. Mytilus edulis: $1.55-\mathrm{cm}$ juveniles to adult specimens. (A) Abfrontal view of a gill filament in a $1.55-\mathrm{cm}$ juvenile. (B) Abfrontal view of a gill lamella in a 1.62-cm juvenile (interlamellar junction in a relaxed position). (C) Detail of the ciliation in the gill arches in a 1.80-cm juvenile. (D) Ventral view of the left budding zone in a $1.75-\mathrm{mm}$ juvenile. (E) Frontal view of gill filaments in an adult specimen (lateral cilia obscured by the latero-frontal cirri). (F) Lateral view of a gill filament in an adult specimen. (G) Abfrontal view of a descending lamella in an adult specimen (ascending lamella removed); inset, detail of an interlamellar junction. (H) Ventral view of the ventral groove of a demibranch in an adult specimen. ac, abfrontal cilia; as, abfrontal surface; fc, frontal cilia; fs, frontal surface; ga, gill arch; gc, apparently grouped cilia; ifcj, interfilamentar ciliary junction; ilj, interlamellar junction; lfc, latero-frontal cirri; lbz, left budding zone; lc, lateral cilia; lfc, latero-frontal cirri; lid, left ID; lod, left OD; m, mantle; o, ostium; sc, simple cilia; sls, sublateral surface; so, small ostium; tz, transition zone; vg, ventral groove. 
arch and dorsal bend in M. edulis adults appears to be a vestigial paedomorphic character, as it is probably functional in postlarvae and juveniles (Stasek, 1962), but not in adults (Ward et al., 1993).

The gill-gill and gill-mantle ciliary junctional systems observed in $M$. edulis postlarvae, juveniles, and adults (present study), and in P. magellanicus adults (Beninger et al., 1988, 1992) are also found in the archaic propeamussid homorhabdic filibranch Bathypecten vulcani (Beninger et al., 2003). These observations suggest that these junctional systems are stable evolutionary characters among filibranch bivalves (Beninger et al., 2003) and are quite different from the gill-gill and gill-mantle tissue fusion seen in eulamellibranchs and pseudolamellibranchs (Ridewood, 1903; Atkins, 1937; Nelson, 1960; Neumann and Kappes, 2003), where tissue fusion is present from the onset of gill development, resulting in a morphologically and functionally different association between mantle and gill. There thus appears to be a clear evolutionary difference between the filibranchs on one hand, and the eulamellibranchs-pseudolamellibranchs on the other hand.

Comparison of gill developmental sequence, ciliation, architecture, and interaction with the other palleal structures highlights the relevance of bivalve gill studies, and especially bivalve gill development, both in phylogenetic studies and in the investigation of the evolution of particle processing systems (Waller, 1998; Giribet and Wheeler, 2002; Tëmkin, 2006).

\section{Acknowledgments}

We thank F. Cornette (IFREMER) for technical support at the La Tremblade hatchery, P. Rosa (Université de Nantes) for helping with specimen collection, and A. Barreau (Université de Nantes) for assistance in SEM. Mytilus edulis specimens were taken from the rearing batches of the European project Blue Seed (Craft 017729) “Technology development for a reliable supply of high quality seed in blue mussel farming." We thank editor M. Greenberg for his extraordinarily detailed suggestions and comments, which have greatly strengthened this manuscript.

\section{Literature Cited}

Allen, J. A. 1961. The development of Pandora inaequivalvis (Linné). J. Embryol. Exp. Morphol. 9: 252-268.

Ansell, A. D. 1962. The functional morphology of the larva, and the post-larval development of Venus striatula (Da Costa). J. Mar. Biol. Assoc. U.K. 42: 419-443.

Atkins, D. 1931. Notes on the regeneration of the gill of Mytilus edulis. J. Mar. Biol. Assoc. U.K. 17: 551-566.

Atkins, D. 1937. On the ciliary mechanisms and interrelationships of lamellibranchs. Part III: Types of lamellibranch gills and their food currents. Q. J. Microsc. Sci. 79: 375-421.

Atkins, D. 1938. On the ciliary mechanisms and interrelationships of lamellibranchs. Part VII: Latero-frontal cilia of the gill filaments and their phylogenetic value. Q. J. Microsc. Sci. 80: 345-433.
Baker, S. M., and R. Mann. 1994. Description of metamorphic phases in the oyster Crassostrea virginica and effects of hypoxia on metamorphosis. Mar. Ecol. Prog. Ser. 104: 91-99.

Bayne, B. L. 1971. Some morphological changes that occur at the metamorphosis of the larvae of Mytilus edulis. Pp. 259-280 in Fourth European Marine Biology Symposium, D. J. Crisp, ed. Cambridge University Press, Cambridge.

Beninger, P. G., and R. Cannuel. 2006. Acquisition of particle processing capability in the oyster Crassostrea gigas: ontogeny of the mantle pseudofeces rejection tracts. Mar. Ecol. Prog. Ser. 325: 153-163.

Beninger, P. G., and S. C. Dufour. 2000. Evolutionary trajectories of a redundant feature: lessons from bivalve gill abfrontal cilia and mucocyte distributions. Pp. 273-278 in The Evolutionary Biology of the Bivalvia, E. M. Harper, J. D. Taylor, and J. A. Crame, eds. Special Publication 177, Geological Society, London.

Beninger, P. G., and S. D. St-Jean. 1997. The role of mucus in particle processing by suspension-feeding marine bivalves: unifying principles. Mar. Biol. 129: 389-397.

Beninger, P. G., M. Le Pennec, and M. Salaün. 1988. New observations of the gills of Placopecten magellanicus (Mollusca: Bivalvia), and implication for nutrition. I. General anatomy and surface microanatomy. Mar. Biol. 98: 61-70.

Beninger, P. G., J. E. Ward, B. A. MacDonald, and R. J. Thompson. 1992. Gill function and particle transport in Placopecten magellanicus (Mollusca: Bivalvia) as revealed using video endoscopy. Mar. Biol. 114: $281-288$.

Beninger, P. G., S. D. St-Jean, Y. Poussart, and J. E. Ward. 1993. Gill function and mucocyte distribution in Placopecten magellanicus and Mytilus edulis (Mollusca: Bivalvia): the role of mucus in particle transport. Mar. Ecol. Prog. Ser. 98: 275-282.

Beninger, P. G., S. A. P. Dwiono, and M. Le Pennec. 1994. Early development of the gill and implications for feeding in Pecten maximus (Bivalvia: Pectinidae). Mar. Biol. 119: 405-412.

Beninger, P. G., T. M. Potter, and S. D. St-Jean. 1995a. Paddle cilia fixation artefacts in pallial organs of adult Mytilus edulis and Placopecten magellanicus (Mollusca, Bivalvia). Can. J. Zool. 73: 610-614.

Beninger, P. G., S. D. St-Jean, and Y. Poussart. 1995b. Labial palps of the blue mussel Mytilus edulis (Bivalvia: Mytilidae). Mar. Biol. 123: 293-303.

Beninger, P. G., A. Veniot, and Y. Poussart. 1999. Principles of pseudofeces rejection on the bivalve mantle: integration in particle processing. Mar. Ecol. Prog. Ser. 178: 259-269.

Beninger, P. G., S. C. Dufour, P. Decottignies, and M. Le Pennec. 2003. Particle processing mechanisms in the archaic, peri-hydrothermal vent bivalve Bathypecten vulcani, inferred from cilia and mucocyte distributions on the gill. Mar. Ecol. Prog. Ser. 246: 183-195.

Bierne, N., C. Daguin, F. Bonhomme, P. David, and P. Borsa. 2003. Direct selection on allozymes is not required to explain heterogeneity among marker loci across a Mytilus hybrid zone. Mol. Ecol. 12: 2505-2510.

Caddy, J. F. 1969. Development of mantle organs, feeding and locomotion in postlarval Macoma balthica (L.) (Lamellibranchiata). Can. J. Zool. 47: 609-617.

Cannuel, R., and P. G. Beninger. 2006. Gill development, functional and evolutionary implications in the Pacific oyster Crassostrea gigas (Bivalvia: Ostreidae). Mar. Biol. 149: 547-563.

Chaparro, O. R., J. A. Videla, and R. J. Thompson. 2001. Gill morphogenesis in the oyster Ostrea chilensis. Mar. Biol. 138: 199207.

Creek, G. A. 1960. The development of the lamellibranch Cardium edule L.. Proc. Zool. Soc. Lond. 135: 243-260.

D'Asaro, C. N. 1967. The morphology of the larval and postlarval Chione cancellata Linné (Eulamellibranchia: Veneridae) reared in the laboratory. Bull. Mar. Sci. 17: 949-972. 
Dral, A. D. G. 1967. The movements of the latero-frontal cilia and the mechanisms of particle retention in the mussel (Mytilus edulis L.). Neth. J. Sea Res. 3: 391-422.

Dufour, S. C., and P. G. Beninger. 2001. A functional interpretation of cilia and mucocyte distributions on the abfrontal surface of bivalve gills. Mar. Biol. 138: 295-309.

Fankboner, P. V., and M. E. De Burgh. 1978. Comparative rates of dissolved organic carbon accumulation by juveniles and pediveligers of the Japanese oyster Crassostrea gigas Thunberg. Aquaculture 13: 205-212.

Field, I. A. 1922. Biology and economic value of the sea mussel, Mytilus edulis. Bull. Bur. Fish. 38: 127-259.

Foster-Smith, R. L. 1975. The role of mucus in the mechanism of feeding in three filter-feeding bivalves. Proc. Malacol. Soc. Lond. 41: $571-588$.

Giribet, G., and W. Wheeler. 2002. On bivalve phylogeny: a high-level analysis of the Bivalvia (Mollusca) based on combined morphology and DNA sequence data. Invertebr. Biol. 121: 371-324.

Gosling, E. M. 2003. Bivalve Molluscs: Biology, Ecology and Culture. Fishing News Books, Blackwell, Oxford.

Gros, O., L. Frenkiel, and M. Mouëza. 1998. Gill filament differentiation and experimental colonization by symbiotic bacteria in aposymbiotic juveniles of Codakia orbicularis (Bivalvia: Lucinidae). Invertebr. Reprod. Dev. 34: 219-231.

Hawkins, A. J. S., and B. L. Bayne. 1992. Physiological interrelations, and the regulation of production. Pp. 171-222 in The Mussel Mytilus: Ecology, Physiology, Genetics and Culture, E. Gosling, ed. Developments in Aquaculture and Fisheries Science, Vol. 25. Elsevier, Amsterdam.

Hodgson, C. A., and R. D. Burke. 1988. Development and larval morphology of the spiny scallop, Chlamys hastata. Biol. Bull. 174: 303-318.

Jackson, R. T. 1890. Phylogeny of the Pelecypoda. The Aviculidae and their allies. Mem. Boston Soc. Nat. Hist. 4: 277-400, pl. 23-30.

Jones, H. D., and O. G. Richards. 1993. The effects of acetylcholine, dopamine, and 5-hydroxytryptamine on water pumping rate and pressure in the mussel Mytilus edulis L. J. Exp. Mar. Biol. Ecol. 170: $227-240$.

Jones, H. D., O. G. Richards, and S. Hutchinson. 1990. The role of ctenidial abfrontal cilia in water pumping in Mytilus edulis L. J. Exp. Mar. Biol. Ecol. 143: 15-26.

Jones, H. D., O. G. Richards, and T. A. Southern. 1992. Gill dimensions, water pumping rate and body size in the mussel Mytilus edulis $\mathrm{L}$. J. Exp. Mar. Biol. Ecol. 155: 213-237.

Kingzett, B. C. 1993. Ontogeny of suspension feeding in post-metamorphic Japanese scallops, Patinopecten yessoensis. M.S. thesis, Simon Fraser University, British Columbia, Canada.

Korniushin, A. V. 1996. Growth and development of the outer demibranch in freshwater clams (Mollusca, Bivalvia): a comparative study. Ann. Zool. 46: 111-124.

Korniushin, A. V. 1997. Patterns of gill structure and development as taxonomic characters in bivalve Molluscs (Mollusca, Bivalvia). Ann. Zool. 46: 245-254.

Lacaze-Duthiers, H. 1856. Mémoire sur le développement des branchies des mollusques acéphales lamellibranches. Ann. Sci. Nat. B 5: 5-47.

Leibson, N. L., and O. T. Movchan. 1975. Cambial zones in gills of Bivalvia. Mar. Biol. 31: 175-180.

Lutz, R. A., and M. J. Kennish. 1992. Ecology and morphology of larval and early postlarval mussels. Pp. 53-85 in The Mussel Mytilus: Ecology, Physiology, Genetics and Culture, E. Gosling ed. Developments in Aquaculture and Fisheries Science, Vol. 25. Elsevier, Amsterdam.

Manahan, D. T. 1983. The uptake and metabolism of dissolved amino acids by bivalve larvae. Biol. Bull. 164: 236-250.
Manahan, D. T. 1990. Adaptations by invertebrate larvae for nutrient acquisition from seawater. Am. Zool. 30: 147-160.

Marshall, T. C., and K. Lee. 1991. Uptake of dissolved glycine by sea scallop (Placopecten magellanicus (Gmelin, 1791)) larvae. Pp. 60-66 in An International Compendium of Scallop Biology and Culture: a Tribute to James Mason, S. E. Shumway and P. A. Sandifer, eds. World Aquaculture Society, Baton Rouge, LA.

Møhlenberg, F., and H. U. Riisgård. 1978. Efficiency of particle retention in 13 species of suspension feeding bivalves. Ophelia 17: 239-246.

Moore, H. J. 1971. The structure of the latero-frontal cirri on the gills of certain lamellibranch molluscs and their role in suspension feeding. Mar. Biol. 11: 23-27.

Nelson, T. C. 1960. The feeding mechanism of the oyster. II. On the gills and palps of Ostrea edulis, Crassostrea virginica and C. angulata. J. Morphol. 107: 163-191.

Neumann, D., and H. Kappes. 2003. On the growth of bivalve gills initiated from a lobule-producing budding zone. Biol. Bull. 205: 73-82.

Newell, C. R., S. E. Shumway, T. L. Cucci, and R. Selvin. 1989. The effects of natural seston particle size and type on feeding rates, feeding selectivity and food resource availability for the mussel Mytilus edulis Linnaeus, 1758 at bottom culture sites in Maine. J. Shellfish Res. 8: $187-196$

Ó Foighil, D., B. Kingzett, G. Ó Foighil, and N. Bourne. 1990. Growth and survival of juvenile Japanese scallops, Patinopecten yessoensis, in nursery culture. J. Shellfish Res. 9: 135-144.

Owen, G. 1974. Studies on the gill of Mytilus edulis: the eu-latero-frontal cirri. Proc. R. Soc. Lond. B 187: 83-91.

Owen, G., and J. M. McCrae. 1976. Further studies on the latero-frontal tracts of bivalves. Proc. R. Soc. Lond. B 194: 527-544.

Quayle, D. B. 1952. Structure and biology of the larva and spat of Venerupis pullustra (Montagu). Trans. R. Soc. Edinb. 62: 255-297.

Raven, C. P. 1958. Morphogenesis: the Analysis of Molluscan Development. Pergamon, New York.

Reid, R. G. B. 1991. Feeding behavior of early juvenile shellfish, with emphasis on the Manila clam. Pp. 50-54 in Remote Setting and Nursery Culture for Shellfish Growers, T. Y. Nosho and K. K. Chew, eds. Washington Sea Grant Program, University of Washington, Seattle.

Reid, R. G. B., R. F. McMahon, D. Ó Foighil, and R. Finnigan. 1992. Anterior inhalant currents and pedal feeding in bivalves. Veliger 35: 93-104.

Rice, E. L. 1908. Gill development in Mytilus. Biol. Bull. 14: 61-77.

Rice, M. A., K. Wallis, and G. C. Stephens. 1980. Influx and net flux of amino acids into larval and juvenile European flat oysters, Ostrea edulis (L.). J. Exp. Mar. Biol. Ecol. 48: 51-59.

Ridewood, W. G. 1903. On the structure of the gills of the lamellibranchia. Philos. Trans. R. Soc. Lond. B 195: 147-284.

Riisgård, H. U., A. Randløv, and P. S. Kristensen. 1980. Rates of water processing, oxygen consumption and efficiency of particle retention in veligers and young post-metamorphic Mytilus edulis. Ophelia 19: $37-47$

Riisgård, H. U., P. S. Larsen, and N. F. Nielsen. 1996. Particle capture in the mussel Mytilus edulis: the role of latero-frontal cirri. Mar. Biol. 127: $259-266$.

Salvini-Plawen, L. v., and G. Steiner. 1996. Synapomorphies and plesiomorphies in higher classification of Mollusca. Pp. 29-51 in Origin and Evolutionary Radiation of the Mollusca, J. Taylor ed. The Malacological Society of London, Oxford University Press, London.

Seed, R., and T. H. Suchanek. 1992. Population and community ecology of Mytilus. Pp. 87-169 in The Mussel Mytilus: Ecology, Physiology, Genetics and Culture, E. Gosling, ed. Developments in Aquaculture and Fisheries Science, Vol. 25, Elsevier, Amsterdam.

Silverman, H., J. W. Lynn, and T. H. Dietz. 1996. Particle capture by 
the gills of Dreissena polymorpha: structure and function of laterofrontal cirri. Biol. Bull. 191: 42-54.

Silverman, H., J. W. Lynn, P. G. Beninger, and T. H. Dietz. 1999. The role of latero-frontal cirri in particle capture by the gills of Mytilus edulis. Biol. Bull. 197: 368-376.

Silverman, H., J. W. Lynn, and T. H. Dietz. 2000. In vitro studies of particle capture and transport in suspension-feeding bivalves. Limnol. Oceanogr. 45: 1199-1203.

Stasek, C. R. 1962. Aspects of ctenidial feeding in immature bivalves. Veliger 5: 78-79.

Sunila, I., and R. Lindström. 1985. The structure of the interfilamentar junction of the mussel (Mytilus edulis L.) gill and its uncoupling by copper and cadmium exposures. Comp. Biochem. Physiol. 81: 267272.

Tëmkin, I. 2006. Morphological perspective on the classification and evolution of recent Pterioidea (Mollusca: Bivalvia). Pp. 253-312 in Bivalvia: a Look at the Branches, R. Bieler ed. Zool. J. Linn. Soc. 148.

Veniot, A., V. M. Bricelj, and P. G. Beninger. 2003. Ontogenic changes in gill morphology and potential significance for food acquisition in the scallop Placopecten magellanicus. Mar. Biol. 142: 123131.

Waller, T. R. 1981. Functional morphology and development of veliger larvae of the European oyster, Ostrea edulis Linné. Smithson. Contrib. Zool. 328: $1-70$

Waller, T. R. 1998. Origin of the molluscan class Bivalvia and a phylogeny of major groups. Pp. 1-45 in Bivalves: an Eon of Evolution: Paleobiological Studies Honoring Norman D. Newell, P. A. Johnston and J. W. Haggart, eds. University of Calgary Press, Calgary, Alberta, Canada.

Ward, J. E., P. G. Beninger, B. A. MacDonald, and R. J. Thompson. 1991. Direct observations of feeding structures and mechanisms in bivalve molluscs using endoscopic examination and video image analysis. Mar. Biol. 111: 287-291.

Ward, J. E., B. A. MacDonald, R. J. Thompson, and P. G. Beninger. 1993. Mechanisms of suspension feeding in bivalves: resolution of current controversies by means of endoscopy. Limnol. Oceanogr. 38: 265-272.

Wilson, J. 1887. On the development of the common mussel (Mytilus edulis, L.). Fifth Ann. Rep. Fish. Board Scotl. for 1886/87. App. F, VI: 247-56.

Wotton, R. S. 1988. Dissolved organic material and trophic dynamics. BioScience 38: 172-178.

Yonge, C. M. 1926. Structure and physiology of the organs of feeding and digestion in Ostrea edulis. J. Mar. Biol. Assoc. U. K. 14: 295-386. 